\title{
Samsun Tekkeköy ilçesindeki süt sığırcılık işletmelerinin yapısal özellikleri ve hijyen koşulları
}

\section{The structural features and hygiene conditions of dairy farms in Tekkeköy district of Samsun province}

\author{
Ali KAYGISIZ1* iD, insan ÖZKAN² iD \\ ${ }^{1}$ Kahramanmaraş Sütçü İmam Üniversitesi, Ziraat Fakültesi, Zootekni Bölümü, Kahramanmaraş \\ ${ }^{2}$ Tekkeköy Tarım ve Orman İlçe Müdürlüğü, Tekkeköy, Samsun \\ ${ }^{1}$ https://orcid.org/0000-0002-5302-2735; ${ }^{2}$ https://orcid.org/0000-0002-4675-8787
}

To cite this article:

Kaygısız, A. \& Özkan, i. (2021). Samsun Tekkeköy ilçesindeki süt sığırcılık işletmelerinin yapısal özellikleri ve hijyen koşulları. Harran Tarım ve Gıda Bilimleri Dergisi, 25(2): 225233.

DOI: $10.29050 /$ harranziraat.879606

Address for Correspondence: Ali KAYGISIZ

e-mail:

alikaygisiz@ksu.edu.tr

Received Date:

15.02.2021

Accepted Date:

22.05.2021

(C) Copyright 2018 by Harran University Faculty of Agriculture. Available on-line at www.dergipark.gov.tr/harranziraat

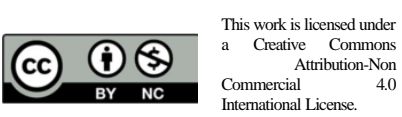

\section{Öz}

Bu çalışmada Tekkeköy (Samsun) ilçesindeki süt sığırcılığı işletmelerindeki hijyen uygulamaları ve yapısal özellikleri incelenmiştir. İşletme sahiplerinin ortalama yaşı $53.1 \pm 10.74$ yıl, ortalama tecrübe süresi $36.2 \pm 14.66$ yıl, ortalama aile büyüklüğü $5.2 \pm 1.91$ kişi, süt birliğine üyelik durumu \% 62.5 olarak tesbit edilmiştir. Ortalama büyükbaş hayvan sayısı $24.4 \pm 21.1$ baş, sağmal inek sayısı $7.5 \pm 5.15$ baş olarak tespit edilmiştir. İşletmelerdeki makinalı sağım oranı \%69 olup işletmecilerin \%100'ünün sağım öncesinde ve sonrasında ellerini ve ineklerin memelerini yıkadıkları, \%37,5'inin sağım kaplarının yıkanmasında temizlik malzemesi kullandığı edilmiştir. Yine işletmecilerin \%87.5'inin ayrı bir önlük kullandığı \%37,5'inin sağım sırasında eldiven kullandığı tesbit edilmiştir. İşletmecilerin hijyen konusunda herhangi bir eğitim almamakla beraber \%65'inin sağılan sütü süzdüğü, \%2,5'inin düzenli mastitis kontrolü yaptığı tespit edilmiştir

Anahtar Kelimeler: Sağım hijyeni, Yapısal özellikler, Süt sığırcılık işletmeleri

\section{ABSTRACT}

The study was conducted to determine structural features and hygiene practices of the dairy cattle farms in Samsun Tekkeköy Province. The results indicated that the averages of; enterprise holder's age, experience periods, household size and member of any agricultural organization were found $53.1 \pm 10.74$ year, $36.2 \pm 14.66$ year, $5.2 \pm 1.91$ head and $62.5 \%$, respectively. The average number of animals and the number of cows per farm was determined as $24.4 \pm 21.1$ head and $7.5 \pm 5.15$ head. Based on survey results, $69 \%$ of farm use milking machine and $100 \%$ of which apply teat cleansing during the milking processes, $37.5 \%$ of them used cleaning materials in washing the milking equipment. In addition, it was determined that $37.5 \%$ of farmers uses gloves during milking, $87.5 \%$ of them use a separate glove. Although the farmers received no training on hygiene, it was determined that $65 \%$ of milk was filtered, and $2.5 \%$ of which was regularly checked for mastitis.

Key Words: Milking hygine, Structural features, Dairy Cattle Farms

\section{Giriş}

Sağlıklı süt elde etmenin en önemli yollarından biri de başarılı bir sürü sağlığı ve sürü yönetimidir (Eser ve Bilgücü, 2019). Sütün kalitesinin artırılması ise sağım öncesi ve sonrasında alınan hijyen tedbirlerini almakla mümkündür. Sağımda kullanılan ekipmanların ve memelerin hijyeni ile sağımcının hijyen kurallarına uyması olarak tanımlanan sağım hijyeni, özellikle sağım sonrası 
ortaya çıkabilecek mikrobiyal bulaşmanın önlenmesi, başta mastitis olmak üzere salgın hayvan hastalıklarının önlenmesi ve tedavi masraflarının azaltılması açısından önemlidir (Eser ve Bilgücü, 2019).

Süt üreten işletmelerde üretimin yüksek olmasının yanı sıra, üretilen sütün hijyenik olması ve ineklerinde sürü ömrünün uzun olması arzulanan özelliklerin başında gelmektedir. Sürü ömrünü etkileyen unsurlardan en önemlisi ise meme sağlığıdır. Son yıllarda sürü sağlığı ve hijyeninin ön plana çıkması ile yapılan çeşitli anket çalışmalarında yetiştiricilerin sürü sağlığı ve sağım hijyenine yönelik deneyim ve bilgi düzeylerinin tespit edilmesine yönelik Türkiye' nin farklı illerinde yapılmış değişik çalışmalar bulunmaktadır. Tekirdağ ìli süt sığırcılığı işletmelerinde sağım öncesi meme başlarının yıkanması, kurulanması, daldırma (teat dipping), ön sağım ve ön sütün kontrolü, kuru dönem idaresi ve meme sağlığı kontrollerinin neredeyse hiç uygulanmadığı bildirilmiştir (Tosun ve Baki Acar, 2019). İzmir ili Ödemiş ilçesi süt sığırcılığı işletmelerinde yapılan bir başka çalışmada ise yetiştiricilerin \%98.9'unun sağım öncesi meme temizliği yaptığı, \%85.9'unun su, \%13.0'ü kuru silme ile yaparken, \%1.1'i ise memeyi temizlemedikleri bildirilmiştir (Yaylak ve ark., 2016). Kars ili süt sığırcılık işletmelerinde ise sağımların \%78.4'ünün elle yapıldığı, işletmelerin \%52.5'inde meme temizliği yapıldığı, meme temizliği yapılan işletmelerin $\% 80$ 'inde sağımdan önce memenin yıkandığı tespit edilmiştir (Demir ve ark., 2014)

Bu araştırma Samsun ili Tekkeköy Illçesindeki sığır işletmelerin genel yapısal özellikleri çerçevesinde süt sağımında hijyenik koşulları ortaya koymak ve değerlendirmek amacıyla yapılmıştır.

\section{Materyal ve Metot}

Tekkeköy İlçesi Samsun il merkezine 14 km, uluslararası Samsun Çarşamba Havaalanına 7 km uzaklıkta olup ilçeden Karadeniz transit yolu geçmektedir. Nüfusu 52.247 olup rakımı 14 metredir. İlçede 3750 işletmede 23.500 büyükbaş hayvan mevcudu bulunmakla beraber anket çalışması en az 3 baş sağmal ineği bulunan işletmelerde uygulanmıştır. Buna göre anket uygulamasında evren büyüklüğü 800 kişidir. Maksimum örnek hacmine ulaşmak amacıyla G*Power 3.0.10 yazılımı (Faul ve ark., 2007) kullanılmıştır. Priori power analizi $T$ testi yaklaşımıyla yapılmıştır. Buna göre, etki büyüklüğü (d) 0.29; 0.80 güç (1-6); \%95 güven aralığında ve 0.05 hata payı $(\alpha)$ ile minimum örnek hacmi 76 olarak hesaplanmıştır. Bu hesaplamaya göre, bu çalışma anketlerin eksik ya da tutarsız olabileceği de göz önünde tutularak araştırmaya katılmayı kabul eden 80 kişi ( $n$ ) ile yürütülmüştür. Çalışmanın yapılabilmesi için KSÜ Fen ve Mühendislik Etik Kurulundan 04.02.2021 tarih ve 2 sayılı karar ile etik kurul izni, Samsun Tekkeköy Tarım ve Orman i̇lçe Müdürlügünden 21.09.2020 tarih ve 2639574 sayılı yazı ile yasal izin alınmıştır.

Araştırmada ilçede yer alan süt sığır işletmelerinin genel yapısı, sağım koşulları, hijyen yapısı hakkında incelemeler ve değerlendirmeler yapılmıştır. Araştırmanın materyalini işletme sahipleri ve sorumlu kişilerle yüz yüze anket metoduyla elde edilen veriler oluşturmuştur. Çalışma kapsamında Tekkeköy ilçesinde 60 mahalle içinde 38 mahallede 80 işletme sahipleriyle anket çalışması yapılırken ilçenin araç ve personelinden yararlanılmıştır. Bunun için anket yapılacak işletme sahiplerine önceden telefonla iletişim sağlanarak konu hakkında bilgi verilmiştir.

Anket formlarındaki veriler MS-Excel programına aktarılarak hesaplamalar yapılmıştır. Ankette sınıflama yapılmadan alınan bazı verilerin ortalama ve standart hatalarının istatistik hesaplamasında SAS paket programı (Orhan ve ark., 2004) kullanılmıştır. Tanımlayıcı istatistik ile frekans analizi yapılarak bazı değerlerin sınıf aralıkları belirlenmiştir. Veriler çizelgeler haline getirilerek özetlenmiş ve her bir alt gruba ait \%değerleri ve ortalamaları verilmiştir. Bazı sağım ve hijyen özellikleri ile süt birliğine üyelik şekli arasındaki ilişkilerin önemlilik düzeyinin belirlenmesinde ki-kare yöntemi uygulanmıştır. 


\section{Bulgular ve Tartışma}

\section{Demografik yapı}

Anket yapılan İşletme sahiplerinin demografik özelliklerine göre dağılımı Çizelge 1'de verilmiştir.

İşletmecilerin \%83.75'i erkek, kalan \%16.25'i ise kadındır. Hayvancılık

faaliyetlerinin yürütülmesinde zaten önemli ölçüde bayan işgücü yer almaktadır. Ancak araştırma sonuçları Karadeniz bölgesinde kadın işgücü doğrudan yönetim/işletmeci konumunda önemli katkılar sağladığını ortaya koymaktadır. Nitekim bu çalışma bulgularına benzer olarak Ordu ilinde işletmecilerin \%6'sinin (Alkan ve Güney, 2019), Samsun ilinde ise \%8.6 kadın olduğu (Kılıç ve Aydın Eryılmaz, 2020) bildirilmiştir.

Çizelge 1. İşletme sahiplerinin demografik özellikleri Table 1. Demographic characteristics of enterprise owners.

\begin{tabular}{|c|c|c|c|}
\hline Özellik (Traits) & Seçenek (Option) & $\mathbf{N}$ & $\%$ \\
\hline \multirow[t]{2}{*}{ Cinsiyet (Sex) } & Erkek (Male) & 67 & 83.75 \\
\hline & Kadın (Female) & 13 & 16.25 \\
\hline \multirow[t]{3}{*}{ Yaş Aralığı (Age) } & $20-40$ & 14 & 17.50 \\
\hline & $40-60$ & 50 & 62.50 \\
\hline & $60-80$ & 16 & 20.00 \\
\hline \multirow{3}{*}{$\begin{array}{l}\text { Eğitim Durumu } \\
\text { (Education) }\end{array}$} & ilköğretim (Primary) & 73 & 91.25 \\
\hline & Lise (High School) & 5 & 6.25 \\
\hline & Üniversite (University) & 2 & 2.50 \\
\hline \multirow{3}{*}{$\begin{array}{l}\text { Mesleki Deneyim } \\
\text { (Experience) }\end{array}$} & $1-20$ & 14 & 17.50 \\
\hline & $20-40$ & 35 & 43.75 \\
\hline & +40 & 31 & 38.75 \\
\hline \multirow{2}{*}{$\begin{array}{l}\text { Süt Birliği Üyelik } \\
\text { (Membership) }\end{array}$} & Üye (Member) & 50 & 62.50 \\
\hline & Üye Değil(Not member) & 30 & 37.50 \\
\hline \multirow{2}{*}{$\begin{array}{l}\text { Sosyal Güvence } \\
\text { (Social security) }\end{array}$} & Var (Yes) & 45 & 56.00 \\
\hline & Yok (No) & 35 & 44.00 \\
\hline \multirow{2}{*}{$\begin{array}{l}\text { Çiftçilik dışında } \\
\text { meslek } \\
\text { (Occupation other } \\
\text { than farming) }\end{array}$} & Var (Yes) & 20 & 25.00 \\
\hline & Yok (No) & 60 & 75.00 \\
\hline \multirow{3}{*}{$\begin{array}{l}\text { Aile nufusu } \\
\text { (Family } \\
\text { population) }\end{array}$} & $1-5$ & 51 & 64.00 \\
\hline & $6-10$ & 27 & 34.00 \\
\hline & $11-15$ & 2 & 2.00 \\
\hline \multirow{2}{*}{$\begin{array}{l}\text { Tarımsal Faaliyet } \\
\text { (Agricultural } \\
\text { Activity) }\end{array}$} & Hayvansal (Animal) & 34 & 42.50 \\
\hline & $\begin{array}{l}\text { Hayvansal + Bitkisel } \\
(\text { Animal+Field })\end{array}$ & 46 & 57.50 \\
\hline
\end{tabular}

İşletme sahiplerinin yaşı ortalama $53.1 \pm 10.74$ yıl olarak tespit edilmiştir. İlçe genelinde $20-40$ yaş grubundaki yetiştiricilerin oranı (\%17.50) daha düşük bulunmaktadır. Diğer taraftan 40-60 yaş grubundaki yetiştiricilerin oranı ise $\% 62.50$ olarak tespit edilmiştir. Bu durum yetiştiricilerin 40 ve ileri yaşlarda işletmeyi sahiplenebildiğini göstermektedir. Tekkeköy ilçesindeki işletmelerde elde edilen ortalama yaş değeri aralıkları Karadeniz Bölgesinde daha önce yapılan çalışmalar (Nuray ve Demir, 2012; Alkan ve Güney, 2019) ile uyum içerisindedir. Bu çalışmada elde edilen bulgularla uyumlu olarak işletme sahiplerinin ortalama yaşı Finlandiya'da (Shalström ve ark., 2014) yapılan bir araştırma 47 yıl, Etiyopya'da ise 51.3 yıl (Duguma ve ark., 2012) olarak bildirilmiştir.

İşletme sahiplerinin \%91.25 gibi önemli bir kısmını ilköğretim mezunları oluşturmaktadır. Ayrıca, ankete katılan işletme sahiplerinin \%6.25'inin lise, \%2.5'inin üniversite mezunu olduğu tespit edilmiştir. Yine Giresun ilinde yapılan diğer çalışmalarda tahsili olmayanlar, ilkokul, ortaokul ve lise mezunlarına ait oranlar sırasıyla \%19, \%54.2, \%17.4 ve \%9.1 (Tugay ve Bakır, 2009) ve $\% 2.28, \% 78.15, \% 15.63$ ve \%3.19 (Alkan ve Ünlü, 2019) olarak bildirilmiştir. Bu çalışmanın yapıldığı bölgede eğitim düzeyi daha düşük bulunmuştur. İsletmecilerin sahip olduğu eğitim düzeyi ile işletmelerde elde edilen verimlilik arasında bir ilişki bulunmakta olup genellikle eğitim düzeyinin yüksek olduğu bölgelerde tarımsal üretimin daha bilinçli yapıldığı bilinmektedir (Şahin ve Yılmaz, 2008).

Sığırcılık işletmelerinde deneyim sürelerinin tespiti açısından üreticilerin süt sığırcılığı ile uğraşma sürelerinin bilinmesi büyük önem taşımaktadır. İşletmecilerin ortalama deneyim süresi $36.2 \pm 14.66$ yıl olarak hesaplanmıştır. Yetiştiricilerin \%17.5'i 1-20 yıl, \%43.75'i 20-40 yıl, $\% 38.75$ ' i ise 40 yıl ve üzeri süt sığırcılığı deneyimine sahiptir. Süt sığırcılığı yapma süreleri incelendiğinde 20-40 yıl ve $+40 \mathrm{yıl}$ aralığında deneyime sahip yetiştiricilerin oranının (\%80) daha fazla olduğu tespit edilmiştir. $\mathrm{Bu}$ durum yetiştiricilerin hayvancılığı sürdürülebilir kıldıklarının göstergesi olarak değerlendirilebilir. Yetiştiricilerin büyük çoğunluğunun zaten bir bitkisel üretim (özellikle de fındık tarımı) ile uğraşıyor olmaları deneyim sürelerinin yüksek çıkmasına neden olmuştur. Diğer yandan, işletmecilerin \%25'inin tarım dışındaki alanlarda da faaliyet gösterdikleri tespit edilmiştir. 
Yetiştiricilerin \%62.5 inin Tekkeköy ilçesi süt üreticileri birliği'ne olduğu anlaşılmaktadır. Herhangi bir tarımsal örgüte üye olan yetiştiricilerin oranı Aydın ilinde \%93.9 (Kayar, 2011), Iğdır ilinde \%82.1 (Yılmaz ve ark., 2020), Konya ilinde \%66.24 (Akkuş, 2009), Giresun ilinde \%46.59 (Alkan ve Ünlü 2019), Kırşehir ilinde \%40 (Çelik, 2014), Muş ilinde \%39.3 (Bakır ve Kibar, 2020), Kars ilinde \%35 (Demir ve Aral, 2009), Kahramanmaraş ilinde \%28 (Eren, 2006) ve \%18 (Kaygısız ve ark., 2009), Rize ilinde \%21.5 (Savaş ve Yenice, 2016), Ağrı ilinde \%3.8 (Bakan ve Aydın, 2016) olarak bildirilmiştir. Kılıç ve Aydın Eryılmaz (2020) Samsun ilinde işletme büyüklüğünün artmasına bağlı olarak Süt Üreticileri Birliği ile Damızlık Sığır Yetiştiricileri Birliği'ne üye yöneticilerin oranı arttığını bildirmişlerdir. Son yıllarda uygulamaya konulan hayvancilık desteklemelerinin yetiştirici birlikleri aracılığıyla yapılması nedeniyle süt üreticileri birliğine üyelik oranının yüksek olduğu belirlenmiştir.

İşletme sahiplerinin \%56'sının bir sosyal güvenceye sahip olduğu tespit edilmiştir. Tarım işi ile uğraşan ve sosyal güvenceye sahip olan yetiştiricilerin oranı Ordu ilinde \%76.79 (Alkan ve
Güney, 2019), Ağrı ilinde \%43.4 (Bakan ve Aydın, 2016), Sivas ilinde \%42.2 (Hozman 2014), Giresun ilinde \%94 (Demir ve Sancar, 2012) olarak tespit edilmiştir.

İşletmelerin \%64 gibi büyük bir çoğunluğunun hane halkı sayısı 1-5 arasında olup ortalama hane büyüklüğü $\quad 5.3 \pm 1.91 \quad$ kişi/işletme olarak hesaplanmıştır. Yine Karadeniz bölgesinde yapılan çalışmalarda hane genişliğinin Ordu ilinde işletmelerinin \%70.9'unda 3 kişiden oluştuğu (Alkan ve Güney, 2019), Rize ili Merkez ilçeye bağlı köylerdeki işletmelerde ise \%90.6'sının 1-5 kişiden oluştuğu (Savaş ve Yenice, 2016) bildirilmiştir.

İsletmecilerin \%42.5'inde sadece hayvansal üretim yapılırken $\% 57.5^{\prime}$ inde bitkisel üretimin yanı sıra hayvansal üretim de yapılmaktadır. Bu durum bölge tarımında hayvancılığın genellikle bitkisel üretim yanında ikincil bir faaliyet olarak yürütüldüğünü ve aile ihtiyacına yönelik olarak sürdürüldüğünü göstermektedir.

Tarımsal kapasite ve barınak özellikleri

Anket yapılan işletmelerin tarımsal kapasite ve barınak özellikleri Çizelge 2'de verilmiştir.

Çizelge 2. İşletmelerin tarımsal büyüklük ve barınak özellikleri

Table 2. Agricultural size and of barn characteristics of the enterprises

\begin{tabular}{|c|c|c|c|c|c|c|c|}
\hline Özellik (Traits) & Seçenek(Option) & $\mathbf{N}$ & $\%$ & Özellik (Traits) & Seçenek (Option) & $\mathbf{N}$ & $\%$ \\
\hline \multirow{5}{*}{$\begin{array}{c}\text { BBHS } \\
X \pm S x \\
24.4 \pm 21.34\end{array}$} & $3-20$ & 48 & 60.00 & \multirow[t]{2}{*}{ Ahır Tipi (Barn Type) } & Geleneksel(Traditional) & 44 & 55.00 \\
\hline & $21-40$ & 24 & 30.00 & & Modern (Modern) & 36 & 45.00 \\
\hline & $41-60$ & 3 & 2.50 & \multirow{5}{*}{$\begin{array}{l}\text { Ahır Kapasitesi } \\
\text { (Barn Capacity) }\end{array}$} & $1-20$ & 41 & 51.25 \\
\hline & $61-80$ & 3 & 3.75 & & $21-40$ & 27 & 33.75 \\
\hline & +81 & 2 & 3.75 & & $41-60$ & 5 & 6.25 \\
\hline \multirow{4}{*}{$\begin{array}{c}\text { Sağmal İnek Sayısı } \\
\text { (Number of Milking Cows) } \\
\text { X } \pm \text { Sx } \\
7.5 \pm 5.15\end{array}$} & $2-5$ & 31 & 38.75 & & $61-80$ & 6 & 8 \\
\hline & $6-10$ & 34 & 42.50 & & $81-100$ & 1 & 1.25 \\
\hline & $11-15$ & 10 & 12.50 & \multirow{2}{*}{$\begin{array}{l}\text { Ahır Havalandırma } \\
\text { (Barn Ventilation) }\end{array}$} & Doğal (Natural) & 78 & 97.50 \\
\hline & +16 & 1 & 1.25 & & Mekanik (Mechanical) & 2 & 2.50 \\
\hline
\end{tabular}

Ortalama büyükbaş hayvan sayısı (BBHS) 24.4 baş olup 3-20 baş ve 21-40 BBHS barındıran işletme sayısı sırasıyla \%60 ve \%30'dur. İşletmelerin $\% 80$ 'inde sağmal inek sayısı 2-10 baş arasında olup ortalama sağmal inek sayısı 7.5 baş'tır. Hayvan sayısı ile benzer doğrultuda ahır kapasitelerinin \%68'i 40 baş'ın altındadır. Ahırların sadece \%36'sı modern tipte olup neredeyse tamamına yakını (\%97.50) doğal havalandırma özelliğine sahiptir.

\section{Irkların dağılımı}

Anket yapılan işletmelerdeki sağmal ineklerin ırklara göre dağılımları Çizelge 3 'de verilmiştir.

Çizelge 3. Irkların dağılımı ve yağ oranları

Table 3. The distribution of races and fat ratios

\begin{tabular}{|c|c|c|c|}
\hline Irk (Breed) & $\mathrm{N}$ & $\%$ & Yağ Oranı (Fat\%) \\
\hline Simental (Simmental) & 228 & $(\% 39)$ & Orta \\
\hline Jersey (Jersey) & 170 & $(\% 29)$ & İyi \\
\hline Siyah Alaca (Holstein) & 76 & $(\% 13)$ & Orta \\
\hline Esmer (Brown Swiss) & 72 & $(\% 12)$ & Orta \\
\hline Yerli (Native) & 34 & $(\% 6)$ & Orta \\
\hline
\end{tabular}


Esasen bugüne kadar yapılan çalışmalarda genel olarak Karadeniz bölgesinde Jersey ırkının yaygın olduğu bilinmekte idi. Nitekim, Savaş ve Yenice (2016) Rize ilinde Jersey ırkının çoğunlukta olduğunu, az sayıda da Esmer ve Siyah Alaca ırkı sığır bulunduğunu bildirmiştir. Ancak bu çalışmada elde edilen sonuçlar Jersey ırkının sayısal çoğunluğunu kaybettiğini göstermektedir. İşletmecilerin adaptasyon yeteneğinin biraz daha iyi olması sebebiyle Simental ırkını (\%39) tercih ettiği, yağ oranının yüksek olması sebebiyle Jersey ırkını (\%29) tercih ettiği, süt veriminin yüksek olması sebebiyle Siyah Alaca(\%13) ve Esmer (\%12) ırklarını tercih ettiği tesbit edilmiştir. İşletme şartları yeterli olmayan yetiştiriciler ise Yerli ırkı (\%6) tercih etmişlerdir. Daha önce Karadeniz bölgesinde yapılan çalışmalarda Yerli ırk oranı
Giresun'da \%23.6 (Tugay ve Bakır, 2009), \%19.27 (Alkan ve Ünlü, 2019), Gümüşhane'de ise \%6.2 (Demir ve Sancar, 2012) olarak bildirilmiştir.

\section{İsletmelerde hijyen alışkanlıkları}

Gıda güvenliğinin öneminin anlaşılmasıyla beraber süt üretiminde de hijyen kavramı ön plana çıkmıştır. Sağım sırasında alınan hijyenik önlemler süt kalitesinde önemli bir artış sağlanmaktadır. Sağım anında kullanılan alet ekipmanlar ile memenin temizlenmiş olmasının bakteri sayısı düşük, sağlıklı, kaliteli çiğ süt elde etmenin ne kadar önemli olduğu ortaya çıkarmıştır. Bazı sağım ve hijyen özellikleri ile süt üreticileri birliği üyeliği arasındaki ilişkiler Çizelge 4 'de bir araya getirilmiştir.

Çizelge 4. Bazı sağım ve hijyen özellikleri

Table 4. Some hygiene and milking traits

\begin{tabular}{|l|c|c|c|c|c|c|}
\hline & \multicolumn{2}{|c|}{$\begin{array}{c}\text { Sağım şekli } \\
\text { (Form of milking) }\end{array}$} & $\begin{array}{c}\text { Süt kabı TM ile yıkanıyor mu } \\
\text { (Is the milk jug washed?) }\end{array}$ & \multicolumn{2}{c|}{$\begin{array}{c}\text { Sağımda eldiven kullanımı } \\
\text { (Use of gloves on milking) }\end{array}$} \\
\hline Üyelik (Memmership) & $\begin{array}{c}\text { Elle(by } \\
\text { hand) }\end{array}$ & Makina(Machine) & Evet (Yes) & Hayır (No) & $\begin{array}{c}\text { Evet (Yes) } \\
\text { Hayır } \\
\text { (No) }\end{array}$ \\
\hline Evet (Yes) & 10 & 40 & 24 & 26 & 24 & 26 \\
\hline Hayır (No) & 15 & 15 & 6 & 24 & 6 & 24 \\
\hline Oran (Ratio) & 0.31 & 0.69 & 0.375 & 0.625 & 0.375 & 0.625 \\
\hline & $\chi^{2}=7.8545^{*}$ & $\chi^{2}=5.8121^{*}$ & & $\chi^{2}=5.8121^{*}$ \\
${ }^{*} \mathrm{P}<0.05$ & & &
\end{tabular}

Sağımların makine ile yapılması ve sağım öncesi meme temizliğinin yapılması hijyen acısından ilk alınabilecek önlemlerdir. Anket yapılan işletmelerin \%31'inde sağımlar elle, \%69'unda ise makine ile yapılmaktadır. Makine ile sağım oranı süt üreticileri birliğine üye işletmelerde $\% 80$ iken üye olmayan işletmelerde \%50 oranında kalmıştır. Süt üreticileri birliğine üyelik durumunun sağım şekline etkisi önemli $(\mathrm{P}<0.05)$ bulunmuştur. Bu çalışmada \%69 olarak tespit edilen makine ile sağım yapan işletme oranı Erzurum ili (Aksoy ve Denizli, 2012), Aydın ili (Kurtaslan ve Doğaner, 2014), Erzindan ili (Özyürek ve ark., 2014), Kars ili (Demir, 2011; Tilki ve ark., 2019), Iğdır ili (Yılmaz ve ark., 2020) süt sığırcılığı işletmeleri için bildirilen değerden daha yüksek bulunmuştur.

Gerek işçilik masraflarının düşürülmesi ve gerekse sağım hijyeni açısından daha ekonomik olması nedeniyle süt sığırcılık işletmelerinde sağım makinalarının kullanımının önemini her geçen gün artırmaktadır. Nitekim, yapılan bir çalışmada işletmelerdeki sağım şekline, DSYB üyeliğinin etkisinin önemli $(\mathrm{P}<0.01)$ bulunduğu tespit edilmiştir (Kaygısız ve ark., 2008).

Çalışma yapılan işletmelerde işletme sahiplerinin, hijyen konusunda bugüne kadar bilgi ve eğitim almadıkları, yaygın bir meme hastalığı olan mastitis'e karşı sadece 2 üreticinin düzenli mastitis kontrolü yaptığı, diğerlerinin ise herhangi bir kontrol yapmayıp hastalık görüldüğünde veteriner kliniklerine başvurduğu, süt sağımında sağım öncesi ve sonrasında meme temizliğinin sıvı sabun ve dezenfektanlar ile yapıldığı tespit edilmiştir. Bu uygulamanın en kısa sürede yükseltilmesi konusunda yetiştiricilerin alışkanlıklarını değiştirmesi ve bu amaçla eğitim çalışmalarında sağım öncesi meme hijyeni ve temizliği konusuna daha fazla önem verilmesi 
gerekliliği sonucu ortaya çıkmaktadır.

İşletmelerin \%37.5'inde sağım kaplarının yıkanmasında temizlik malzemesi kullanılmakta, \%67.5'inda ise herhangi bir temizlik maddesi kullanılmamaktadır. Temizlik malzemesi kullanım oranı üye işletmelerde \%48 iken üye olmayan işletmelerde $\% 30$ oranında kalmıştır. Süt birliğine üyelik durumunun temizlik malzemesi kullanımına etkisi önemli $(P<0.05)$ bulunmuştur.

İşletmelerin \%37.5'inde sağımda eldiven kullanılmakta, \%67.5'inda ise eldiven kullanılmamaktadır. Eldiven kullanım alışkanlığı üye işletmelerde $\% 48$ iken üye olmayan işletmelerde \%30 oranında kalmıştır. Süt birliğine üyelik durumunun sağımda eldiven kullanım alışkanlığına etkisi önemli $(P<0.05)$ bulunmuştur.

Işletmelerin \%65'inde sağımdan sonra süt süzülmekte, \%35'inde ise herhangi bir süzme işlemi yapılmamaktadır. Sağımdan sonra sütü süzme alışkanlığı üye işletmelerde \%72 iken üye olmayan işletmelerde \%53 oranında kalmıştır. Süt birliğine üyelik durumunun sağımdan sonra sütü süzme alışkanlığına etkisi önemli $\quad(P<0.05)$ bulunmuştur.

Anket yapılan işletmelerin $\% 76^{\prime}$ sında ahır temizliği günde $2 \mathrm{kez}$ \%24'ünde ise $1 \mathrm{kez}$ yapılmaktadır. Günde iki kez sağım oranı üye işletmelerde \%74, üye olmayan işletmelerde ise $\% 80$ olmuştur.

Ankete katılan yetiştiricilerin tamamı (\%100) hijyen konusunda bilgi sahibi olmayıp kendi bilgileri doğrultusunda temizlik yaptıklarını, herhangi bir hijyen eğitimine katılmadıklarını bildirmişlerdir. Ancak buna rağmen işletmecilerin tamamı sağımdan önce ineklerin memelerini ve süt kovalarını yıkadıklarını, sağımdan sonra ise sütü süzdüklerini, süzme aletini de yıkadıklarını ifade etmişlerdir.

Yetiştiricilerin tamamı sürülerinde mastitis dolayısı ile tedavi almakta olan hayvanları olmadığını, herhangi bir antibiyotik tedavisi sırasında sağılan sütü kullanmadıklarını ancak düzenli mastitis kontrolü yapan işletmecilerin oranının ise $\% 2.5$ olduğu tespit edilmiştir.

Elle sağım yapan işletmecilerin tamamının (\%100) sağımdan önce/sonra ellerini ve süt kablarını yıkadıklarını tespit edilmiştir. Çeşitli araştırmalarda sağımdan önce meme temizliği yapan işletmelerin oranları; Ankara ve Aksaray illerinde \%98.4 ve \%96.5 (Tatar, 2007), Tekirdağ ilinde \%96 (Soyak ve ark., 2007), Erzincan ili Çayırlı ilçesinde \%93.3 (Özyürek ve ark., 2014), Erzurum ili Hınıs ilçesinde \%\%85 (Koçyiğit ve ark., 2016), Kahramanmaraş ilinde \%78 (Kaygısız ve ark., 2008), Tokat ilinde \%66.6 (Ildız, 1999), Erzurum ili Narman ilçesinde \%54.4 (Koçyiğit ve ark., 2017), Kars ilinde \%52.5 (Demir ve ark., 2014) olarak tespit edilmiştir.

İşletmecilerin \%87.5'inin sağım için ayrı bir kıyafet/önlük kullandığı ancak aynı kıyafetle ahır temizliğini de yaptıkları tespit edilmiştir.

Makine ile sağım yapan işletmelerin \%67'sinin sağım makinasını ahır dışında bir depoda tuttuğunu, \%16'sı sağımdan önce sağım makinasını yıkadığını, \%100' ünün ise sağımdan sonra da sağım makinasını temizlik malzemesi kullanarak yıkadığı tespit edilmiştir. Iğdır ili süt sığırcılığı işletmelerinde \%80.8 oranında meme temizliği yapıldığı (Yılmaz ve ark., 2020), Azerbaycan'ın Bakü ilinde ise işletmelerin tamamında meme temizliğinin hiçbir temizleyici madde kullanmadan, dezenfekte edilmemiş bez yardımıyla yapıldığı bildirilmiştir (Kılıç ve ark. 2020).

Sağmal inek başına süt verimi $6 \mathrm{kğ} \mathrm{olan}$ işletmelerin günde 1 sağım yaptığı (\%7.5), 10 kğ olan işletmelerin ise günde iki sağım yaptığı (\%92.5) tespit edilmiştir. İşletmeciler elle yapılan sağımların 7-10 dk arası, makine ile yapılan sağımların ise 4-6 dk sürdüğünü bildirmişlerdir. Yine günlük süt üretimi düşük olan işletmelerin (\%55) sütü gün aşırı pazarladıkları, diğer işletmelerin (\%45) ise sütü günlük olarak pazarladıkları tesbit edilmiştir.

Yetiştiriciler sütün pazarda satılması durumunda ise yazın 1-4 saat, kışın ise 1-5 saat dışarıda beklediğini ifade etmişlerdir.

İşletmelerin sağmal hayvan kapasitelerinin az olması (7.25 baş/işletme) sebebiyle ayrı bir sağım bölmesi bulunmamaktadır.

Sağım sırasında yetiştiricilerin neredeyse tamamının her bir hayvanın sütünü aynı sağım kabına üst üste biriktirerek sağdığı, sağımdan sonra 
sütün buzdolabında muhafaza edildiği tespit edilmiştir.

Araştırma kapsamındaki işletmelerin tamamı kapalı tip işletmeler olup; 2'sinde mekanik havalandırma, 78'inde doğal havalandırma yöntemleri kullanılmaktadır. İşletmelerin 46'sında (\%57.5) hem hayvansal hem bitkisel üretim yapılırken 34'ünde (\%42.5) sadece hayvansal üretim yapılmaktadır.

Satılan süt ve süt ürünlerinin çoğunluğunun semt pazarları ve evden satışı şeklinde gerçekleştirildiği, kalanlarının da toptancı ve süt işletmelerine verilmek suretiyle aile bütçelerine katkı sağlayıp geçimlerinin çoğunluğunu tarım ve hayvancılıktan sağladıkları tespit edilmiştir. İşletmecilerden 4 kişinin sütleri ayrı kaplara koyarak, 76 kişinin ise tüm sütleri üst üste biriktirip 1-2 gün içinde buzdolabında muhafaza ederek pazardan/evden/şirketlere satış yaptığı, süt dağıtımında kullanılan kapların çoğunun kendilerince ${ }_{2}$ bir kısmımın da alıcılar tarafından temin edildiği, ahır temizliğini 61 kişi sabah akşam 19 kişi günde 1 defa olmak üzere ahırı süpürerek/çektirerek/yıkayarak yaptığı, tüm bu işletmedeki çalışmalarında hep aynı kıyafetleri kullandığı tespit edilmiştir.

\section{Sonuç ve Öneriler}

Çalışmanın yürütüldüğü ilçede hayvancılık işletmelerindeki yapısal durum ve hijyen özelliklerinin Türkiye'deki bazı illerden daha iyi durumda olmakla beraber, yine de uygulamalar bakımından önemli problemlerin olduğu tespit edilmiştir.

İlçedeki süt işletmelerinde barınakların durumu ve uygun barınak tiplerinin seçimi mastitis problemi açısından en önemli sorun olmaya devam etmektedir. Süt işletmelerinde yapılan bu çalışmada hijyen şartlarının ineklerde mastitisin gelişmesinde etkili olabilmekte, meme hijyenine dikkat edilmesi, işletme şartlarına uygun bir mastitis kontrol programının oluşturulması, merkezi sağım sistemlerinin kurularak sürü sağlığı ve sürü yönetiminin sağlanması gerekmektedir.

Yetiştiricilerin hijyen konusunda güncel bilgilere sahip olmadıkları gözlenmiştir. $\mathrm{Bu}$ nedenle memede mastitis gibi rahatsızlıkların ortaya çıkmaması için yetiştiricilere meme temizliğinin nasıl yapılması gerektiği konusunda bilgilendirme yapılmalıdır.

Hayvan üretim yapan işletmelerde, verimi artırmanın en önemli kurallarından biri yüksek verimli ırklarla yetiştiricilik yapmaktır. İlçede dört farklı ırkın yaygın olduğu gözlenmiştir. Bölge şartlarına uygun ırkın tespit edilerek yetiştiricilere tavsiye edilmesi gerekmektedir.

Bölgedeki barınakların yarıya yakını geleneksel tipte olup, modern havalandırma sistemi yok denecek kadar azdır. Bölge şartlarına uygun göre uygun barınak tipinin yaygınlaştırılması için eğitim faaliyetleri düzenlenmeli, yeterli havalandırmanın önemi yetiştiricilere anlatılmalıdır. Üretilen sütlerin sağımdan sonra bekletilmesi sütün içerdiği bakterilerin hızla çoğalmasına sebep olduğundan sağımdan hemen sonra sütün soğutulması gerekmektedir. Bu nedenle işletmelerde süt soğutma tankının bulunması gerekmektedir. Ayrıca sağım ekipmanlarının belirli periyotlarda temizliklerinin yapılması hem daha sağlıklı süt üretimine imkan verecek hem de süt sığırcılığının en büyük problemi olan mastitisin önlenmesini sağlayacaktır.

Benzer çalışmaların artırılmasıyla mevcut durumun doğru bir şekilde tespit edileceği ve yapılacak öneriler dikkate alındığında süt sığırcılığında bir adım daha ileri gidilebileceği düşünülmektedir.

\section{Ekler}

$\mathrm{Bu}$ çalışma İhsan ÖZKAN'ın aynı isimli Mezuniyet Çalışmasından alınmıştır.

Çıkar Çatışması Beyanı: Makale yazarları aralarında herhangi bir çıkar çatışması olmadığını beyan ederler.

Yazar Katkısı: İhsan ÖZKAN çalışmaya ait anketleri yapmış, Ali KAYGISIZ verileri analiz etmiş, makale ile ilgili literatür taraması yapmış ve makaleyi yazmışlardır. 


\section{Kaynaklar}

Akkuş, Z. (2009). Konya ilindeki süt sığırcılığı işletmelerinin yapısal özellikleri. (Yayınlanmamış Yüksek Lisans Tezi). Selçuk Üniversitesi Fen Bil. Enstitüsü, Konya.

Aksoy, A., \& Denizli, G. (2012). Erzurum ili damızlık sığır yetiştiricileri birliği faaliyetlerinin değerlendirilmesi. Atatürk Üniversitesi Ziraat Fakültesi Dergisi, 43(2), 123-131.

Alkan, S., \& Güney, Z. (2019). Ordu ili sığırcılık işletmelerinin yapısal özelliklerinin belirlenmesi. Mediterranean Agricultural Sciences, 32(3), 447-452/ https:// doi.org/10.29136/mediterranean.586726

Alkan, S., \& Ünlü, H. (2019). Giresun ilindeki sığırcılık işletmelerinin genel yapısının belirlenmesi. Mediterranean Agricultural Sciences, 32(1), 109-115/ https://doi.org/10.29136/mediterranean.474790

Bakan Ö, \& Aydın R. (2016). Ağrı İli Süt Sığırcılığı İşletmelerinin Sosyo-Ekonomik Özellikleri. Atatürk Üniv. Ziraat Fak. Derg., 47 (2), 113-122.

Bakır G, \& Kibar M. (2020). Muş ìli Süt Sığırcılığı İşletmelerinin Bazı Yapısal Özelliklerinin Belirlenmesi. KSÜ Tarım ve Doğa Derg 23 (6), 1687-1697. DOI: 10.18016/ksutarimdoga.vi.694060/https://doi.org/1 0.18016/ksutarimdoga.vi.694060

Çelik C. (2014). Kırşehir ili merkez ilçede sığır besiciliği yapan işletmelerin ekonomik analizi. (Yayınlanmamış Yüksek Lisans Tezi). Erciyes Üniversitesi Sağlık Bilimleri Enstitüsü, Türkiye.

Demir, N., \& Sancar, C. (2012). Gümüşhane ili ve çevresinde süt sığırcılığı yapan işletmelerin sosyal, ekonomik ve teknik Analizi. Alınteri Dergisi 23 (B), 18-28.

Demir, P. (2011). Kars îlindeki Süt Üreticilerinin Bazı Teknik Bilgi Düzeylerinin Araştırılması. Atatürk Üniversitesi Veteriner Bilimleri Dergisi, 6 (1) , 47-54 .

Demir, P., Adıgüzel, S. I., Sarı, M., \&Ayvazoğlu, C. (2014). Kars merkez ilçedeki süt sığırcılık işletmelerinin genel yapısı ve ekonomik boyutu. Fırat Üniversitesi Sağlık Bilimleri Veteriner Dergisi, 28(1), 9-13.

Duguma, B., Kechero, Y., \&Janssens G.P.J. (2012). Survey of major diseases affecting dairy cattle in jimma town, Oromia, Ethiopia. Global Veterinaria, 8 (1), 62-66.

Eren, E., 2006. Kahramanmaraş ili Göksun ilçcesinde Sığır Besiciliği Yapan İşletmelerin Yapısı ve Sorunları (Yayınlanmamış Yüksek Lisans Tezi). Kahramanmaraş Sütçü İmam Üniversites, Fen Bilimleri Enstitüsü, KahramanMaraş.

Eser AG, \& Bilgücü E. (2019). Sütçü İneklerde Meme Sağlığı ve Sağım Hijyeninin Önemi. Internatıonal Conference on Awareness Proceedings, 05-07 December 2019, Çanakkale.

Faul, F., Erdfelder, E., Lang, A. G., \& Buchner, A. (2007). G* Power 3: A flexible statistical power analysis program for the social, behavioral, and biomedical sciences. Behavior research methods, 39(2), 175-191.

Hozman, S.B. (2014). Sivas ili damızlık sığır yetiştiricileri birliğine üye süt sığırcılığı işletmelerinde hayvan besleme uygulamaları. (Yayınlanmamış Yüksek Lisans Tezi) Adnan Menderes Üniversitesi Fen Bilimleri Enstitüsü, Aydın.
Kayar, Y. (2011). Denizli yöresi süt sığırcılığı işletmelerinde barınakların yapısal yönden değerlendirilmesi. (Yayınlanmamış Yüksek Lisans Tezi). Adnan Menderes Üniversitesi Fen Bilimleri Enstitüsü, AYDIN.

Kaygısız, A., Tümer, R., Orhan, H., \& Vanlı, Y. (2008). Kahramanmaraş bölgesi süt sığırı işletmelerinin yapısal özellikleri: I. Yetiştirme uygulamaları. Süleyman Demirel Üniversitesi Ziraat Fakültesi Dergisi., 3(2), 23-31.

Kılıç, I., Yaylı, B., \& Alakbarov, A. (2020). Bakü ilinde Faaliyet Gösteren Süt Sığırı İşletmelerinin Yapısal Durumu ve Değerlendirilmesi. Bursa Uludağ Üniversitesi Ziraat Fakültesi Dergisi, 34(2), 237-253.

Kılıç, O., \& Eryılmaz, GA. (2020). Samsun ilinde süt sığırcılığı yapan işletmelerin yapısal özellikleri. Türk Tarım ve Doğa Bilimleri Dergisi, 7(3), 637-645/ https://doi.org/10.30910/turkjans.682932

Koçyiğit, R., Aydın, R., Diler, A., Güler, O., \& Yanar, M. (2016). Erzurum İli Hınıs İlçesindeki Sığırcılık İşletmelerinin Yapısal Özellikleri: Sağım Yönetimi. Harran Tarım Ve Gıda Bilimleri Dergisi, 20(4): 322-329/ https://doi.org/10.29050/ harranziraat.282275

Koçyiğit, R., Yanar, M., Aydın, R., Diler, A. \& Güler, O. (2017). Erzurum illi Narman İlçesindeki sığırcılık işletmelerinde uygulanan sağım yönetimi üzerine bir araştırma. Alınteri Zirai Bilimler Dergisi, 32(2), 45-54/ https://doi.org/10.28955/alinterizbd.303907

Kurtaslan, T., \& Doğaner, M. (2004). Çiğ süt pazarlamasında çiftçilerin tarımsal kooperatiflere yaklaşımlarının değerlendirilmesi (Aydın İli Örneği). Türkiye VI. Tarım Ekonomisi Kongresi, 444-451.

Orhan, H., Efe, E., \& Şahin, M. (2004). SAS yazılımı ile istatistiksel analizler. Tuğra Ofset. Isparta.

Önal AR, \& Özder M. (2008). Edirne ili damızıık sığır yetiştiricileri birliğine üye işletmelerin yapısal özellikleri. Tekirdağ Ziraat Fakültesi Dergisi, 5(2), 197203.

Özyürek, S., Kocyigit, R., \& Tüzemen, N. (2014). Erzincan ilinde süt sığırcılığı yapan işletmelerin yapısal özellikleri: Çayırlı İlçesi örneği. Tekirdağ Ziraat Fakültesi Dergisi, 11(2), 19-26

Savaş S, \& Yenici G. (2016). Rize illinde Yapılan Süt Sığırcılığının Mevcut Durumunun Araştırılması. Atatürk Üniversitesi Veteriner Bilimleri Dergisi, 11(1), 74-83/ https://doi.org/10.17094/avbd.60910

Shalström, L., Virtanen, T., Kyyrö, J., \& Lyytikänen, T. (2014). Biosecurity on Finnish cattle, pig and sheep farms results from a questionnaire. Preventive Veterinary Medicine, 117 (1), 59-67/ https://doi.org/10.1016/ j.prevetmed.2014.07.004

Soyak, A., Soysal Mi, \& Gürcan EK. (2007). Tekirdağ ili süt sığırcılığı işletmelerinin yapısal özellikleri ve bu işletmelerin Siyah Alaca süt sığırı popülasyonunun çeşitli morfolojik özellikleri üzerine bir araştırma. Tekirdağ Ziraat Fakültesi Dergisi, 4(3), 297-305

Şahin K., \& Yılmaz iH. (2008). Van ilinde yem bitkileri tarımı, mera kullanımı ve sosyo ekonomik yapı üzerine bir araştırma. Ankara Üniv. Zir. Fak. Tar. Bil. Derg., 14, 414-419.

Tatar, A.M. (2007). Ankara ve Aksaray Damızlık Sığır Yetiştiricileri il Birliklerine Üye Süt Sığırı İşletmelerinin Yapısı ve Sorunları. (Yayınlanmamış Doktora Tezi) Ankara Üniversitesi, Fen Bilimleri Enstitüsü, Ankara. 
Tilki, M., Sarı, M., Aydın, E., Işık, S., \& Aksoy, A. R. (2013). Kars ili sığır işletmelerinde barınakların mevcut durumu ve yetiştirici talepleri: I. Mevcut durum. Kafkas Üniv. Vet. Fak. Derg, 19(1), 109-116/ https://doi.org/ 10.9775/ kvfd.2012.7282

Tosun, S., \& Acar, D.B. (2019). The comparison of milking hygiene with bulk tank somatic cell count and total bacterial count in dairy herds in Tekirdag province. Kocatepe Veterinary Journal, 12(3), 292299.
Yaylak, E., Konca, Y., \& Koyubenbe, N (2016). İzmir İli Ödemiş illçesindeki Damızıı Sığır Yetiştiricileri Birliği Üyesi İşletmelerde Sağlık Koruma Uygulamaları ve Sağlık Sorunları Üzerine Bir Araştırma. Hayvansal Üretim, 57(1), 28-40.

Yılmaz i., Kaylan, V., \&Yanar M. (2020). Iğdır İli Büyükbaş Hayvan Yetiştiriciliğinin Yapısal Analizi. ığdır Üniversitesi Fen Bilimleri Enstitüsü Dergisi, 10(1): 684693/ https://doi.org/10.21597/jist.567366 